Hal. 350 - 365

\title{
STRATEGI PENCAPAIAN OPINI WTPPEMERINTAH KABUPATEN BONDOWOSO DALAM PENERAPAN STANDAR AKUNTANSI PEMERINTAHAN BERBASIS AKRUAL
}

\author{
Heny Setyawati \\ Dinas Tenaga Kerja dan Transmigrasi Kabupaten Bondowoso \\ hen.imut78@gmail.com
}

\begin{abstract}
New Public Management has reformed the financial management of the public sector by adopting approaches from the private sector in order to achieve organizational efficiency and effectiveness (including local and central government finances) and it was the reason behind the implementation of Accrual-based Government Accounting Standards (SAP). The Governmentof Bondowoso also implements accrual-based SAP policy. This study used a qualitative approach by using Strenghts Weaknessess Opportunities Threats (SWOT) analysis in the early stage to describe the strategy and then completed by in depth interview. The informants were 8 (eight) key persons in the Government of Bondowoso with significant roles in achieving the unqualified opinion in implementing the accrual-based SAP. Results show that commitment from the leaders of local government and institutions, financial statements presentation that in line with the SAP, sufficient internal control system, and the follow-up on the State Audit Agency's recommendations on the local government financial statements are the major strengths in achieving the unqualified opinion of the accrual-based SAP. The opportunities in Strength-Opportunity (SO) strategy are the issuance of various laws and regulations and technical guidance of accrual-based accounting standards by the central government.
\end{abstract}

Keywords: Unqualified Opinion, Accrual Based SAP, SWOT, Strategy.

Abstrak: New Public Management telah mereformasi pengelolaan keuangan sektor publik dengan menggunakan pendekatan yang ada pada sektor swasta untuk mencapai efisiensi dan efektivitas penyelenggaraan sektor publik (termasuk pengelolaan keuangan negara dan daerah). Hal tersebut merupakan latar belakang dibuatnya Standar Akuntansi Pemerintah (SAP) berbasis akrual. Pemerintah Kabupaten Bondowoso merupakan salah satu pemerintah daerah yang melaksanakan kebijakan SAPtersebut. Penelitian ini menggunakan pendekatan kualitatif dan memanfaatkan analisis SWOT di awal penelitian guna mendeskripsikan strategi kemudian diperdalam dengan metode in depth interview. Informan sebagai responden analisis SWOT adalah 8 (delapan) pejabat kunci yang berperan penting dalam pencapaian opini Wajar Tanpa Pengecualian (WTP) Pemerintah Kabupaten Bondowoso pada penerapan SAP berbasis akrual. Hasil penelitian menunjukkan bahwa komitmen pemimpin daerah dan pimpinan instansi, penyajian laporan keuangan daerah yang sesuai dengan SAP, sistem pengendalian internal yang memadai, serta penanganan tindak lanjut rekomendasi Badan Pemeriksa Keuangan atas Laporan Keuangan Pemerintah Daerah merupakan kekuatan utama keberhasilan strategi pencapaian opini WTP. Peluang pada strategi SO adalah diterbitkannya 
berbagai peraturan perundang-undangan serta petunjuk teknis tentang standar akuntansi berbasis akrual oleh pemerintah pusat.

Kata Kunci: Opini WTP, SAP Berbasis Akrual, SWOT, Strategi.

\section{Pendahuluan}

Organisasi sektor publik sering digambarkan tidak produktif, tidak efisien, selalu rugi, rendah kualitas, kurang inovasi dan kreativitas serta berbagai kekurangan lainnya. Buruknya pengelolaan organisasi sektor publik memunculkan kritik keras sehingga mendorong terjadinya reformasi manajemen sektor publik. Salah satu gerakan reformasi sektor publik yang paling popular adalah konsep New Public Management yang disingkat NPM (Mahmudi, 2011:34).

Di Indonesia, penerapan konsep NPM dimulai dengan adanya reformasi pengelolaan keuangan negara. Diawali dengan diterbitkannya Undang Undang No. 17 Tahun 2003 tentang Keuangan Negara yang mewajibkan adanya Standar Akuntansi Pemerintahan (SAP) sebagai dasar penyusunan laporan keuangan bagi instansi pemerintah. Kemudian terbit Peraturan Pemerintah Nomor 71 Tahun 2010, yaitu peraturan yang menetapkan standar akuntansi pemerintahan yang disusun berlandaskan pada penggunaan basis akrual.

Opini merupakan pernyataan profesional pemeriksa mengenai kewajaran informasi keuangan yang disajikan dalam laporan keuangan yang didasarkan pada kriteria: kesesuaian dengan standar akuntansi pemerintahan, kecukupan pengungkapan (adequate disclosures), kepatuhan terhadap peraturan perundang-undangan, dan efektivitas sistem pengendalian intern. Terdapat 4 (empat) jenis opini yang dapat diberikan oleh pemeriksa, yakni: opini wajar tanpa pengecualian (unqualified opinion), opini wajar dengan pengecualian (qualified opinion), opini tidak wajar (adversed opinion), dan pernyataan menolak memberikan opini (disclaimer of opinion). (Penjelasan Pasal 16 Ayat (1) UndangUndang Republik Indonesia Nomor 15 Tahun 2004 tentang Pemeriksaan Pengelolaan dan Tanggung Jawab Keuangan Negara)

Standar Akuntansi Pemerintahan, yang selanjutnya disingkat SAP, adalah prinsipprinsip akuntansi yang diterapkan dalam menyusun dan menyajikan laporan keuangan pemerintah (Pasal 1 Peraturan Pemerintah Republik Indonesia nomor 71 tahun 2010 Tentang Standar Akuntansi Pemerintahan).Peraturan Pemerintah Republik Indonesia Nomor 71 Tahun 2010 tentang Standar Akuntansi Pemerintahan dan Peraturan Menteri Dalam Negeri Nomor 64 Tahun 2013 tentang Penerapan Standar Akuntansi Pemerintahan Berbasis Akrual, mewajibkan pemerintah daerah untuk menerapkan Standar Akuntansi Pemerintahan (SAP) Berbasis Akrual paling lambat mulai tahun anggaran 2015. 
Transisi menuju basis akuntansi akrual merupakan sebuah proyek utama bagi kebanyakan pemerintah, seperti halnya proyek skala besar yang memerlukan perencanaan dan pengelolaan cermat. Berdasarkan Guidance Transition to Accrual Basis by IFAC, transisi ini kemungkinan besar akan lancar dan lebih cepat ketika fitur berikut ini dapat terpenuhi:mandat yang jelas, komitmen politik, komitmen entitas pusat dan pejabat kunci, sumber daya yang memadai (manusia dan keuangan), struktur manajemen proyek yang efektif, kapasitas teknologi dan system informasi yang memadai, penggunaan undangundang.

Proses implementasi SAP berbasis akrual perlu dirancang secara hati-hati karena mempunyai implikasi yang tidak dapat dihindari. Implikasi tersebut mencakup mandat yang jelas, komitmen politik, komitmen pemerintah dan pejabat kunci, sumber daya yang memadai, struktur manajemen perubahan yang efektif, dukungan kapasitas teknologi informasi dan sistem informasi yang memadai serta dukungan legislatif.

Salah satu keberhasilan dari penerapan akuntansi akrual pada akhirnya dapat dilihat dalam opini dari hasil pemeriksaan atas laporan keuangan. Terdapat 6 (enam) langkah (komponen) yang perlu diperhatikan agar laporan keuangan pemerintah mendapatkan opini Wajar Tanpa Pengecualian (WTP) yaitu: sistem pembukuan dan perencanaan anggaran, sistem aplikasi teknologi komputer (IT related), inventarisasi aset dan utang, jadwal waktu penyusunan laporan keuangan dan pemeriksaan serta pertanggungjawaban anggaran, quality assurance yang dilakukan oleh pengawas intern, sumber daya manusia.

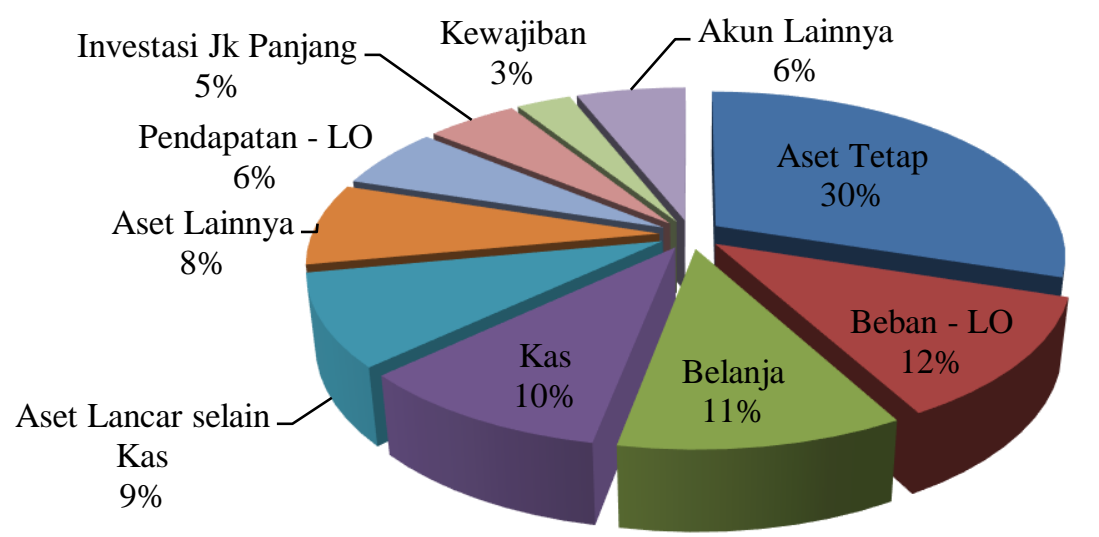

Gambar 1. Akun yang Disajikan Tidak Sesuai SAP Pada LKPD Tahun 2015 Sumber : Ikhtisar Hasil Pemeriksaan BPK Semester I Tahun, 2016

Pada Gambar 1 tersebut dapat dilihat dengan jelas bahwa kendala pencapaian opini WTP yang utama adalah permasalahan aset tetap, karena permasalahan aset tetap memiliki prosentase terbesar dalam pengecualian akun pada LKPD tahun 2014 maupun tahun 2015 sehingga pemerintah daerah perlu memperhatikan dan 
menindaklanjuti rekomendasi-rekomendasi pemeriksaan dari BPK-RI mengenai permasalahan tersebut. Setiap unsur pemerintahan pastinya ingin memperoleh reputasi yang baik, salah satunya melalui opini audit yang baik juga. Hal ini menjadi motivasi setiap daerah dalam menerapkan SAP secara benar.

Tabel 1. Daftar Opini LKPD Tahun 2010 - 2015 Kabupaten Bondowoso dan sekitarnya

\begin{tabular}{lcccccc}
\hline $\begin{array}{c}\text { Entitas Pemerintah } \\
\text { Daerah (LKPD) }\end{array}$ & Tahun & Tahun & Tahun & Tahun & Tahun & Tahun \\
Kab. Banyuwangi & WDP & WDP & WTP & WTP & $\begin{array}{c}\text { WTP } \\
\text { DPP }\end{array}$ & WTP \\
\hline Kab..Bondowoso & WDP & $\begin{array}{l}\text { WTP } \\
\text { DPP }\end{array}$ & WTP & WDP & $\begin{array}{l}\text { WTP } \\
\text { DPP }\end{array}$ & WTP \\
\hline Kab. Jember & WDP & WDP & WTP & WDP & WDP & WTP \\
\hline Kab. Lumajang & WDP & WDP & WDP & WDP & WTP & WTP \\
\hline Kab. Situbondo & WDP & WDP & WDP & WDP & WTP & WDP \\
\hline Kab. Probolinggo & WDP & WDP & WDP & WTP & WTP & \multirow{2}{*}{ WTP } \\
\hline Kota Probolinggo & WDP & WTP & WTP & $\begin{array}{l}\text { WTP } \\
\text { DPP }\end{array}$ & WDP & WDP \\
\hline
\end{tabular}

Sumber: Ikhtisar Hasil Pemeriksaan BPK Semester I Tahun 2016

Penelitian ini menggunakan pendekatan penelitian kualitatif, dengan memanfaatkan analisis SWOT di awal penelitian guna mendeskripsikan strategi kemudian diperdalam dengan menggunakan metode in depth interview.

Berdasarkan gambaran tersebut dirumuskan suatu permasalahan sebagai berikut: Bagaimana strategi pemerintah Kabupaten Bondowoso dalam usaha pencapaian opini WTP dalam penerapan standar akuntansi pemerintahan berbasis akrual?

\section{Metodologi}

Penelitian inimenggunakan pendekatan penelitian kualitatif, dengan memanfaatkan analisis SWOT di awal penelitian guna mendeskripsikan strategi kemudian diperdalam dengan menggunakan metode in depth interview. Penelitian ini dilakukan di Pemerintah Kabupaten Bondowoso. Dalam penelitian ini dilakukan serangkaian kegiatan mulai studi orientasi dan studi terfokus. Perancangan data dengan pendekatan wawancara (in - depth interview), observasi, dokumentasi dan triangulasi. 


\section{Subjek dan Objek Penelitian}

Subjek penelitian adalah subjek yang dituju untuk diteliti oleh peneliti. Objek penelitian adalah obyek yang dijadikan penelitian atau yang menjadi titik perhatian suatu penelitian. Dalam penelitian ini yang menjadi subjek penelitian adalah pegawai yang terlibat dalam proses penyusunan laporan keuangan yang menggunakan SAP berbasis akrual pada Pemda Kabupaten Bondowoso, yang menjadi objek penelitian yaitu usaha mendapatkan opini WTP dalam penerapan standar akuntansi pemerintahan berbasis akrual di Kabupaten Bondowoso.

\section{$\underline{\text { Penentuan Informan Penelitian }}$}

Pemilihan informan pertama sebagai informan kunci merupakan hal yang sangat utama sehingga harus dilakukan secara cermat, karena penelitian ini mengkaji tentang usaha pencapaian opini WTP dalam penerapan standar akuntansi pemerintahan berbasis akrual di Kabupaten Bondowoso. Peneliti memfokuskan peneiltian pada pengumpulan data dengan melakukan wawancara (in-depth interview) yang dilakukan kepada :

1. Kepala DPPK Kabupaten Bondowoso

2. Kepala Bidang Akuntansi dan Pelaporan DPPKKabupaten Bondowoso

3. Kepala Seksi Akuntansi DPPK Kabupaten Bondowoso

4. Kepala Seksi Fasilitasi \& Informasi Keuangan DPPK Kab. Bondowoso

5. Irban Inspektorat Kabupaten Bondowoso

6. Kepala Sub Bagian Evaluasi dan Pelaporan Inspektorat Kab. Bondowoso

7. Auditor Inspektorat Kab. Bondowoso

8. Kepala Sub Bagian Pengelolaan dan Pelaporan Aset Setda. Kab. Bondowoso

\section{Desain dan Strategi Penelitian}

Dipengaruhi oleh pandangan bahwa peneliti kualitatif tidak membutuhkan pengetahuan dan teori tentang objek penelitian untuk mensteril subjektifitas peneliti, maka format penelitian dikonstruksi agar peneliti dapat mengembangkan semua pengetahuan dan teorinya setelah mengetahui permasalahannya di lapangan. Karena itu format desainnya adalah sebagai berikut : 


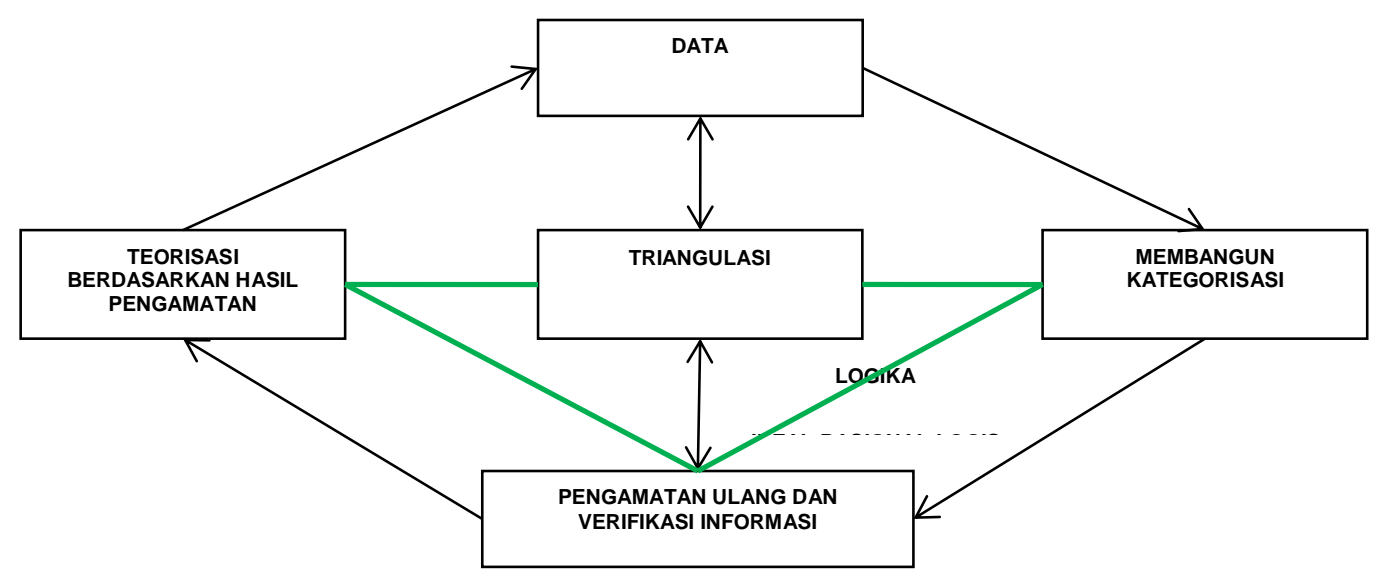

Gambar 2. Desain Penelitian

Sumber: Bungin (2014: 7), dimodifikasi

\section{Analisis SWOT}

Tahap pertama dalam analisis SWOT adalah melakukan identifikasi terhadap faktor-faktor internal dan eksternal di lingkungan Pemerintah Daerah Kabupaten Bondowoso yang dianggap berpengaruh secara positif maupun secara negatif dalam usaha pencapaian opini WTP dalam penerapan standar akuntansi pemerintahan berbasis akrual, kemudian disusun sebuah kuisioner sebagai sarana untuk mendapatkan penilaian dari responden terhadap faktor-faktor yang telah dirumuskan (Rangkuti, 2008).

Penilaian terhadap faktor-faktor yang telah diidentifikasikan dibagi menjadi 2 bagian, yaitu: Penilaian terhadap prestasi faktor. Penilaian pada tahap ini diberikan skala antara 1 sampai dengan 9, dan penilaian urgensi (tingkat kepentingan) terhadap penanganan faktorfaktor. Penilaian pada tahap ini diberikan skala a (bernilai 1) sampai dengan d (bernilai 4).

\section{Pengujian Keabsahan Hasil Penelitian}

Pengujian keabsahan hasil penelitian dalam penelitian ini menggunakan Teknik Pemeriksaan Data Kualitatif (Moleong, 2006: 327) yaitu : perpanjangan keikutsertaan, menemukan siklus kesamaan data, ketekunan pengamatan, triangulasisumber data, metode, dan teori, pengecekan melalui diskusi, kajian kasus negatif, pengecekan anggota tim, kecukupan referensial, uraian rinci, auditing.

\section{Hasil dan Pembahasan}

Analisis SWOT digunakan untuk menjaring persepsi dan penilaian ahli (expert) terhadap faktor internal dan eksternal pada Pemerintah Kabupaten Bondowoso, sehingga pada akhirnya didapatkan faktor kekuatan (Strength), faktor kelemahan Weakneses), faktor peluang (Opportunity), dan faktor ancaman (Threat). Dari penilaian bobot IFAS (Internal Strategic Factor Analysis Summary) dan EFAS (Eksternal Strategic Factor Analysis Summary), didapatkan beberapa alternatif strategi mendapatkan opini WTP dalam 
penerapan standar akuntansi pemerintahan berbasis akrual pada Pemerintah Kabupaten Bondowoso.

Setelah faktor-faktor strategi internal suatu perusahaan diidentifikasi, kemudian menyusun tabel IFAS (Internal Strategic Factor Analysis Summary) untuk merumuskan faktor-faktor strategis internal tersebut dalam kerangka Strength and Weakness organisasi seperti tabel berikut :

Tabel 2. Penilaian Bobot IFAS - EFAS SWOT

\begin{tabular}{|c|c|c|c|c|c|c|}
\hline \multirow{10}{*}{ Strength } & No. & Sub Elemen & Rata2 & Bobot & Rating & Skor \\
\hline & 1. & $\begin{array}{l}\text { Komitmen dan integritas } \\
\text { yang tinggi dari Bupati } \\
\text { Bondowoso beserta Jajaran } \\
\text { Pimpinan Instansi yang } \\
\text { berwenang }\end{array}$ & 7,9 & 0.007 & 3,50 & 0.24 \\
\hline & 5. & Bimtek dan Sosialisasi & 7,5 & 0.066 & 3,25 & 0.22 \\
\hline & 7. & $\begin{array}{l}\text { Sistem Pembukuan dan } \\
\text { Perencanaan Anggaran }\end{array}$ & 7,5 & 0.066 & 3,50 & 0.23 \\
\hline & 8. & $\begin{array}{l}\text { Penyajian laporan keuangan } \\
\text { sesuai dengan SAP }\end{array}$ & 7,6 & 0.067 & 3,50 & 0.24 \\
\hline & 12. & $\begin{array}{l}\text { Pedoman Kerja dan } \\
\text { Pelaksanaan } \\
\text { Pemerintahan Daerah }\end{array}$ & 7,5 & 0.066 & 3,50 & 0.23 \\
\hline & 13. & $\begin{array}{l}\text { SPI yang Memadai Sehingga } \\
\text { Pelanggaran Dapat Dicegah }\end{array}$ & 7,6 & 0.067 & 3,50 & 0.24 \\
\hline & 15. & $\begin{array}{l}\text { Penanganan Tindak Lanjut } \\
\text { Rekomendasi atas Temuan } \\
\text { BPK }\end{array}$ & 7,2 & 0.064 & 3,75 & 0.24 \\
\hline & 16. & $\begin{array}{l}\text { Kepatuhan Terhadap } \\
\text { Perundang-undangan }\end{array}$ & 7,5 & 0.066 & 3,50 & 0.23 \\
\hline & & & & & & 1,87 \\
\hline & 2. & $\begin{array}{lll}\text { Ukuran } & \text { Daerah } & \text { Besar } \\
\text { Sehingga } & \text { Total Aset } & \text { Lebih } \\
\text { Besar dan Kompleks } & \end{array}$ & 6,5 & 0.057 & 3,25 & 0.19 \\
\hline Weakness & 3. & $\begin{array}{l}\text { Jumlah dan Pendidikan } \\
\text { Pegawai }\end{array}$ & 6 & 0.053 & 3,25 & 0.17 \\
\hline & 4. & Ketersediaan Tenaga Ahli & 6,6 & 0.059 & 4,00 & 0.23 \\
\hline
\end{tabular}




\begin{tabular}{|c|c|c|c|c|c|c|}
\hline \multirow{15}{*}{ Strength } & No. & Sub Elemen & Rata2 & Bobot & Rating & Skor \\
\hline & 1. & $\begin{array}{l}\text { Komitmen dan integritas } \\
\text { yang tinggi dari Bupati } \\
\text { Bondowoso beserta Jajaran } \\
\text { Pimpinan Instansi yang } \\
\text { berwenang }\end{array}$ & 7,9 & 0.007 & 3,50 & 0.24 \\
\hline & 5. & Bimtek dan Sosialisasi & 7,5 & 0.066 & 3,25 & 0.22 \\
\hline & 7. & $\begin{array}{l}\text { Sistem Pembukuan dan } \\
\text { Perencanaan Anggaran }\end{array}$ & 7,5 & 0.066 & 3,50 & 0.23 \\
\hline & 8. & $\begin{array}{l}\text { Penyajian laporan keuangan } \\
\text { sesuai dengan SAP }\end{array}$ & 7,6 & 0.067 & 3,50 & 0.24 \\
\hline & 12. & $\begin{array}{l}\text { Pedoman Kerja dan } \\
\text { Pelaksanaan } \\
\text { Pemerintahan Daerah }\end{array}$ & 7,5 & 0.066 & 3,50 & 0.23 \\
\hline & 13. & $\begin{array}{l}\text { SPI yang Memadai Sehingga } \\
\text { Pelanggaran Dapat Dicegah }\end{array}$ & 7,6 & 0.067 & 3,50 & 0.24 \\
\hline & 15. & $\begin{array}{l}\text { Penanganan Tindak Lanjut } \\
\text { Rekomendasi atas Temuan } \\
\text { BPK }\end{array}$ & 7,2 & 0.064 & 3,75 & 0.24 \\
\hline & 16. & $\begin{array}{l}\text { Kepatuhan Terhadap } \\
\text { Perundang-undangan }\end{array}$ & 7,5 & 0.066 & 3,50 & 0.23 \\
\hline & & & & & & 1,87 \\
\hline & 6. & Koordinasi Intensif Antar SKPD & 6,6 & 0.059 & 3,50 & 0.21 \\
\hline & 9. & $\begin{array}{l}\text { Sistem Aplikasi Komputer } \\
\text { Pelaporan Keuangan Daerah } \\
\text { yang Terintegrasi }\end{array}$ & 6,6 & 0.059 & 3,50 & 0.21 \\
\hline & 10. & $\begin{array}{l}\text { Sistem Pengelolaan/ } \\
\text { Manajemen Aset Daerah yang } \\
\text { Terintegrasi }\end{array}$ & 6,6 & 0.059 & 3,00 & 0.18 \\
\hline & 11. & $\begin{array}{l}\text { Jadwal Waktu Penyusunan } \\
\text { Laporan Keuangan dan } \\
\text { Pemeriksaan } \\
\text { Pertanggungjawaban } \\
\text { Anggaran }\end{array}$ & 6,8 & 0.061 & 3,50 & 0.21 \\
\hline & 14. & $\begin{array}{l}\text { Pelanggaran atas Perpres } \\
\text { Pengadaan Barang dan Jasa }\end{array}$ & 6,7 & 0.060 & 3,50 & 0.21 \\
\hline
\end{tabular}




\begin{tabular}{|c|c|c|c|c|c|c|}
\hline \multirow{10}{*}{ Strength } & No. & Sub Elemen & Rata2 & Bobot & Rating & Skor \\
\hline & 1. & $\begin{array}{l}\text { Komitmen dan integritas } \\
\text { yang tinggi dari Bupati } \\
\text { Bondowoso beserta Jajaran } \\
\text { Pimpinan Instansi yang } \\
\text { berwenang }\end{array}$ & 7,9 & 0.007 & 3,50 & 0.24 \\
\hline & 5. & Bimtek dan Sosialisasi & 7,5 & 0.066 & 3,25 & 0.22 \\
\hline & 7. & $\begin{array}{l}\text { Sistem Pembukuan dan } \\
\text { Perencanaan Anggaran }\end{array}$ & 7,5 & 0.066 & 3,50 & 0.23 \\
\hline & 8. & $\begin{array}{l}\text { Penyajian laporan keuangan } \\
\text { sesuai dengan SAP }\end{array}$ & 7,6 & 0.067 & 3,50 & 0.24 \\
\hline & 12. & $\begin{array}{l}\text { Pedoman Kerja dan } \\
\text { Pelaksanaan } \\
\text { Pemerintahan Daerah }\end{array}$ & 7,5 & 0.066 & 3,50 & 0.23 \\
\hline & 13. & $\begin{array}{l}\text { SPI yang Memadai Sehingga } \\
\text { Pelanggaran Dapat Dicegah }\end{array}$ & 7,6 & 0.067 & 3,50 & 0.24 \\
\hline & 15. & $\begin{array}{l}\text { Penanganan Tindak Lanjut } \\
\text { Rekomendasi atas Temuan } \\
\text { BPK }\end{array}$ & 7,2 & 0.064 & 3,75 & 0.24 \\
\hline & 16. & $\begin{array}{l}\text { Kepatuhan Terhadap } \\
\text { Perundang-undangan }\end{array}$ & 7,5 & 0.066 & 3,50 & 0.23 \\
\hline & & 1,60 & & & & 1,87 \\
\hline
\end{tabular}

Sumber: Hasil Pengolahan Data Informan

Setelah faktor-faktor strategi eksternal suatu perusahaan diidentifikasi dilanjutkan dengan menyusun tabel EFAS (Eksternal Strategic Factor Analysis Summary) sebagai hasil dari identifikasi faktor-faktor eksternal yang dikelompokkan menjadi Opportunity and Threat, dengan hasil seperti yang disajikan dalam tabel 3 
Tabel 3 Penilaian Bobot EFAS SWOT

\begin{tabular}{|c|c|c|c|c|c|c|}
\hline & No. & Sub Elemen & Rata2 & Bobot & Rating & Skor \\
\hline & 2. & Sistem Informasi Keuangan & 6,9 & 0.083 & 3.00 & 0.25 \\
\hline & & Daerah yang Disediakan BPKP & & & & \\
\hline & 4. & Bimtek dan Sosialisasi dari & 7,5 & 0.092 & 3.50 & 0.32 \\
\hline & & Pemerintah Pusat & & & & \\
\hline & 5. & Terbitnya Peraturan Pemerintah & 7,5 & 0.092 & 3.50 & 0.32 \\
\hline Opportunity & & No. 71 Tahun 2010 & & & & \\
\hline & 6. & Terbitnya Peraturan Menteri & 7,5 & 0.092 & 3.50 & 0.32 \\
\hline & & Dalam Negeri No. 64 Tahun & & & & \\
\hline & & 2013 & & & & \\
\hline & 7. & Buletin Teknis No. 18 tentang & 7,5 & 0.092 & 3.50 & 0.32 \\
\hline & & Akuntansi Penyusutan Berbasis & & & & \\
\hline & & Akrual & & & & \\
\hline & 8. & Permendagri No. 19 Tahun 2016 & 7,1 & 0.088 & 3.50 & 0.30 \\
\hline & & tentang Pedoman Pengelolaan & & & & \\
\hline & & Barang Daerah & & & & \\
\hline & 9. & Pemberian Dana Insentif Daerah & 7 & 0.086 & 3.13 & 0.27 \\
\hline & & & & & & 2,10 \\
\hline & 1. & Komunikasi Efektif antara & 6,8 & 0.083 & 3.00 & 0.25 \\
\hline & & Pemerintah Daerah dengan & & & & \\
\hline & & DPRD & & & & \\
\hline & 3. & Kuota dan Batasan Rekruitmen & 6,1 & 0.075 & 3.00 & 0.22 \\
\hline & & SDM dari BKN & & & & \\
\hline Threat & 10. & Penundaan penyaluran Dana & 6,3 & 0.077 & 2.75 & 0.21 \\
\hline & & Alokasi Umum & & & & \\
\hline & 11. & Budaya masyarakat yang kurang & 5,9 & 0.070 & 2,50 & 0.17 \\
\hline & & menganggap penting pendidikan & & & & \\
\hline & 12. & Budaya paternalistik dimana & 5,9 & 0.070 & 2,50 & 0.17 \\
\hline & & bertindaknya & & & & \\
\hline & & mengikuti keputusan yang & & & & \\
\hline & & diambil oleh para tokoh. & & & & \\
\hline & & 1,04 & & & & \\
\hline
\end{tabular}

Sumber: Hasil Pengolahan Data Informan

Dari hasil pembobotan IFAS-EFAS elemen SWOT terlihat bahwa faktor kekuatan yang memiliki nilai rata-rata paling tinggi adalah Komitmen dan integritas yang tinggi dari 
Bupati Bondowoso beserta Jajaran Pimpinan Instansi yang berwenang, dengan nilai ratarata sebesar 7,86 . Dengan adanya komitmen, maka faktor penghambat lain dapat segera diatasi melalui kebijakan-kebijakan pimpinan.

Faktor kelemahan yang mendapatkan nilai rata-rata terendah adalah Jumlah dan Pendidikan Pegawai, dengan nilai rata-rata sebesar 6. Hal ini, menurut informan merupakan kelemahan terbesar Kabupaten Bondowoso karena daerah jumlah pegawai yang ada dengan kualifikasi pendidikan berlatar belakang akuntansi kurang memenuhi dari total jumlah pegawai yang dibutuhkan untuk mengelola laporan keuangan.

Faktor peluang yang memiliki nilai rata-rata tertinggi adalah bimtek, sosialisasi dari pemerintah pusat serta terbitnya perundang-undangan tentang SAP berbasis akrual serta peraturan tentang pelaporan keuangan lainnya dengan nilai rata-rata sebesar 7,5 . Berbagai peraturan dari pemerintah pusat menjadi payung hukum dan panduan bagi pemerintah daerah untuk dapat mengaplikasikan perubahan sistem akuntansi dengan baik.

Faktor ancaman yang memiliki nilai rata-rata terendah adalah budaya masyarakat yang kurang menganggap penting pendidikan, dengan nilai rata-rata sebesar 5,9. Artinya, budaya pandalungan pada masyarakat seperti memiliki keyakinan teguh dan berlebihan pada kebenaran yang dipercayainya menimbulkan sikap tidak mau mengenal kompromi, dan seringkali memunculkan pembawaan keras kepala. Pembawaan ini, umumnya dijumpai pada masyarakat yang pendidikannya kurang tinggi dan akibat ketidaktahuan. Pada kondisi ini dapat menghambat usaha mendapatkan opini WTP dalam pelaksanaan SAP berbasis akrual.

Hasil perumusan matriks IFAS - EFAS, menghasilkan strategi SO, ST, WO, dan WT, kemudian dilakukan pembobotan penilaian untuk menentukan skala prioritasnya. Susunan strategi disajikan pada tabel 4

Tabel 4. Pembobotan Hasil Kuesioner SWOT

\begin{tabular}{lll}
\hline & \multicolumn{1}{c}{$\mathrm{S}=1,87$} & \multicolumn{1}{c}{$\mathrm{W}=1,60$} \\
\hline $\mathrm{O}=2,10$ & $\mathrm{SO}=3,97$ & $\mathrm{WO}=3,71$ \\
\hline $\mathrm{T}=1,04$ & $\mathrm{ST}=2,91$ & $\mathrm{WT}=2,64$ \\
\hline
\end{tabular}

Sumber: Hasil Pengolahan Data

Meskipun strategi SO merupakan alternatif strategi terbaik yang memiliki nilai pembobotan yang paling tinggi, namun untuk belum tentu semua strategi-strategi tersebut dapat dilaksanakan secara simultan, sehingga perlu dilakukan prioritas apabila dalam pelaksanaannya secara bersama-sama menemui kendala sumber daya (resources constraints). 


\section{Analisis Hasil In Depth Interview}

Analisis ini mengupas mengenai hasil wawancara (in-depth interview) yang dilakukan kepada para pejabat di lingkungan pemerintah daerah Kabupaten Bondowoso yang dianggap ahli dan memahami dalam merumuskan strategi mendapatkan opini WTP pada penerapan standar akuntansi pemerintahan berbasis akrual di Kabupaten Bondowoso. .

Hasil penelitian di atas sejalan dengan hasil wawancara dengan Kepala Sub Bagian Evaluasi dan Pelaporan Inspektorat Kabupaten Bondowoso yang menyatakan bahwa hal yang paling utama dalam pelaksanaan kebijakan adalah komitmen pimpinan sebagai penguasa dan pemilik sumberdaya, karena apa yang menjadi kebijakan pimpinan akan diamin-i oleh bawahan. Sedangkan Kepala Bidang Akuntansi dan Pelaporan DPPK Kabupaten Bondowoso menekankan bahwa selain komitmen pimpinan juga diperlukan adanya satu komando dalam pelaksanaan semua kebijakan yang telah ditetapkan oleh pemerintah daerah.

\section{Ukuran Daerah}

Ukuran daerah adalah prediktor signifikan untuk kapatuhan akuntansi. Kabupaten/Kota dengan wilayah / luas daerah yang lebih besar maka akan memiliki total aset yang lebih besar sehingga lebih kompleks dalam menjaga dan mengelola asetnya. Data pencatatan aset yang beragam menimbulkan permasalahan pencatatan atau penatausahaan pembukuan aset menjadi pekerjaan yang sangat membutuhkan konsentrasi pemerintah daerah karena golongan aset yang dipersyaratkan harus sesuai standar akuntansi pemerintah tidak semua datanya telah lengkap atau dimiliki dengan benar. Hal tersebut juga disampaikan oleh salah seorang Auditor pada Inspektorat Kabupaten Bondowoso sebagai berikut :

“...Pelaporan asset yang pada akhirnya akan berpusat pada DPPK merupakan kumpulan laporan asset dari berbagai SKPD yang tersebar pada seluruh wilayah di Kabupaten Bondowoso, mulai dari Sekretariat Daerah, Dinas-dinas, Badan, Kantor (termasuk Kecamatan, Kelurahan) sampai unitunit terkecil seperti UPTD, puskesmas, puskesmas pembantu dan sekolahsekolah (SD, SMP, SMA) dimana Aplikasi IT yang telah ada berikut cara pengoperasian serta kebijakan yang telah disusun guna menghasilkan laporan asset yang dibutuhkan masih ada beberapa SDM terkait yang masih kurang pemahamannya."

\section{Sumber Daya Manusia}

Kompetensi SDM meliputi pengetahuan akuntansi dan pengalaman personel dalam menangani urusan-urusan yang menyangkut akuntansi keuangan pemerintahan daerah sangat diperlukan tetapi masih terbatas baik jumlah maupun kualitasnya. Hasil penelitian tersebut sejalan dengan pernyataan yang disampaikan oleh Kepala Seksi Akuntansi DPPK Kabupaten Bondowoso sebagai berikut : 
“...SDM di DPPK pastinya telah dibekali dengan bimtek-bimtek dari pusat dan propinsi yang cukup sering, dan juga Kami memiliki pedoman akuntansi keuangan yang sudah sangat baik. Namun secara internal memang atasan selalu memberikan pesan secara spiritual. Perencanaan kebutuhan kompetensi dan pelatihan SDM yang menangani fungsi keuangan, aset dan TI secara terus menerus dikembangkan. Dalam waktu dekat DPPK akan melaksanakan sosialisasi dan bimtek tentang :Persediaan, Penyusunan laporan keuangan, Piutangdan Saya dengar Bagian Perlengkapan dan Aset juga akan melakukan sosialisasi tentang pengelolaan aset. “

\section{Sarana, Prasarana dan Proses}

Teknologi informasi berperan dalam mempermudah pelaksanaan proses akuntansi pemerintahan (baik hardware maupun software). Adanya suatu aplikasi/sistem yang terintegrasi akan mempermudah para personel untuk mencatat transaksi dan menyusun laporan keuangan pemerintah daerah, baik di tingkat SKPD maupun SKPKD (tingkat konsolidasi).

Kabupaten Bondowoso menyusun laporan keuangan dengan SAP berbasis akrual menggunakan aplikasi SIMDA 2.7.6 dan SIMDA BMD 2.0.0.2 yang dibuat oleh BPKP dimana setiap tahunnya diperbaharui sesuai dengan peraturan perundang-undangan terbaru. Sedangkan secara teknik akuntansi dan metode akuntansi yang lebih terinci Pemerintah Kabupaten Bondowoso memiliki suatu buku prosedur/manual akuntansi pemerintah daerah yang dijelaskan secara lengkap dalam Peraturan Bupati Bondowoso tentang Pedoman Kerja dan Pelaksanaan Tugas Pemerintah Kabupaten Bondowoso dimana buku manual ini selalu dikaji ulang dan diperbaharui setiap tahunnya.

\section{Regulasi dan Kebijakan Daerah}

Regulasi menjadi payung hukum dan panduan bagi pelaku implementasi untuk dapat mengaplikasikan perubahan sistem akuntansi dengan baik (Surepno, 2015). Strategi Pemerintah Kabupaten Bondowoso dalam menyusun laporan keuangan daerah yang sesuai dengan standar akuntansi pemerintahan berbasis akrual seperti termuat dalam Peraturan Pemerintah Nomor 71 Tahun 2010 adalah dengan membuat regulasi dan kebijakan SAP berbasis akrual secara umum maupun secara teknis. Langkah ini ditegaskan oleh Kepala Bidang Akuntansi dan Pelaporan DPPK Kabupaten Bondowoso sebagai anggota penyusun Peraturan Bupati Bondowoso Nomor 59 Tahun 2015 tentang Kebijakan Akuntansi Pemerintah Kabupaten Bondowoso dalam proses wawancara sebagai berikut:

\footnotetext{
“...Strategi yang digunakan Pemkab Bondowoso dalam upaya mencapai opini WTP dalam pelaksanaan SAP berbasis akrual lebih banyak dilakukan dengan pendekatan spiritual, tetapi secara teknis dan kebijakan secara umum juga sudah dibuatkan dengan kreatifitas sendiri yang disesuaikan dengan peraturan serta perundang-undangan yang ada di atasnya."
} 


\section{Sistem Pengendalian Intern}

Faktor utama yang menyebabkan belum tercapainya opini WTP secara penuh adalah masih adanya beberapa temuan Badan Pemeriksa Keuangan (BPK) dalam Sistem Pengendalian Intern (SPI) dan ketidakpatuhan terhadap perundang-undangan. Sistem pengendalian intern pada Pemerintah Kabupaten Bondowoso dituangkan secara terperinci di dalam Peraturan Bupati Bondowoso Nomor 44 Tahun 2016 tantang Pedoman Kerja dan Pelaksanaan Tugas Pemerintah Kabupaten Bondowoso.

Berfungsi sebagai SPI, Pedoman Kerja dan Pelaksanaan Tugas Pemerintah Kabupaten Bondowoso ini memuat hal-hal sebagai berikut : ketentuan umum, penyusunan anggaran kinerja, pengelolaan keuangan daerah, administrasi pengelolaan barang daerah, standar biaya konsumsi dan perjalanan daerah, pembinaan aparatur dan pedoman penyelenggaraan diklat, pedoman pelaksanaan kegiatan/pengadaanbarang/jasa, pedoman umum penyelenggaraan pembangunan bangunan negara/daerah beserta lingkungannya, pedoman penyelenggaraan penyusunan rencana tata ruang, sistem akuntabilitas kinerja instansi pemerintah.

\section{Penanganan Tindak Lanjut}

Tindak lanjut rekomendasi BPK atas Laporan Keuangan Pemerintah Daerah (LKPD) diatur dalam Undang-Undang Nomor 15 Tahun 2004 Tentang Pemeriksaan Pengelolaan dan Tanggungjawab Keuangan Negara, khususnya pasal 21 ayat (1). Tindak lanjut hasil pemeriksaan tahun lalu akan menjadi pertimbangan auditor dalam menentukan resiko audit (Tresnawati dan Apandi, 2016). Pendapat yang sama disampaikan oleh Kepala Sub Bagian Evaluasi dan Pelaporan Inspektorat Kabupaten Bondowoso sebagai berikut:

“... Tindaklanjut BPK itu indikator yang paling mudah dilihat oleh BPK atas komitmen Pemerintah Daerah terhadap usaha memperbaiki Laporan Keuangan Pemerintah Daerah. Kalo dokumen peraturan itu jika ada yang salah masih diberikan kesempatan perbaikan saat pemeriksaan."

\section{Kesimpulan}

Berdasarkan Hasil interaksi IFAS - EFAS yang menghasilkan alternatif strategi, bobot paling tinggi adalah Strength - Opportunity (SO), yang dapat diterjemahkan sebagai strategi menggunakan kekuatan untuk memanfaatkan peluang dengan alternatif strategi sebagai berikut :

1. Kekuatan utama bagi Pemerintah Kabupatan Bondowoso dalam pencapaian opini WTP pada penerapan standar akuntansi pemerintahan berbasis akrual adalah komitmen dan integritas yang tinggi dari Bupati Bondowoso beserta jajaran pimpinan Instansi yang berwenang sehingga semua program, kegiatan, dan kebijakan daerah yang dianggap mendukung pencapaian opini WTP akan didukung 
penuh oleh Bupati beserta pimpinan Instansi. Kekuatan lainnya adalah penyajian laporan keuangan daerah yang telah sesuai dengan SAP berbasis akrual dan SPI yang memadai sehingga pelanggaran terhadap perundang-undangan dapat dicegah, namun masih terdapat kendala yaitu kurangnya kesadaran pegawai pelaksana kegiatan pada SKPD untuk selalu membaca SPI dalam pelaksanaan tugas.

2. Peluang utama bagi Pemerintah Kabupatan Bondowoso dalam pencapaian opini WTP pada penerapan standar akuntansi pemerintahan berbasis akrual adalah terbitnya peraturan - peraturan tentang standar akuntansi pemerintah beserta petunjuk teknisnya antara lain PP No. 71 Tahun 2010, Permendagri No. 64 Tahun 2013, Buletin Teknis No. 18 tentang Akuntansi Penyusutan Berbasis Akrual, serta bimtek dan sosialisasi dari pemerintah pusat.

\section{Saran}

Berdasarkan hasil penelitian dapat diberikan beberapa rekomendasi bagi Pemerintah Kabupaten Bondowoso yaitu sebagai berikut :

1. Pemerintah Kabupaten Bondowoso disarankan untuk segera melakukan pengembangan sistem informasi laporan keuangan dan system management aset yang terintegrasi dengan seluruh SKPD karena kemampuan sistem informasi untuk menyediakan data yang dapat dipercaya, akurat, dan up-to-date secara efektif, merupakan pendukung utama pelaksanaan dan kegunaan sistem manajemen akuntansi.

2. Pemerintah Kabupaten Bondowoso disarankan untuk melakukan monitoring guna memperkuat fungsi Pejabat Penatausahaan Keuangan SKPD dalam mengawal pelaksanaan kegiatan SKPD agar sesuai dengan SPI terutama pelaksanaan Peraturan Bupati Bondowoso Nomor 44 Tahun 2016 tentang Pedoman Kerja Dan Pelaksanaan Tugas Pemerintah Kabupaten Bondowoso Tahun 2017.

3. Pemerintah Kabupaten Bondowoso disarankan untuk secara berkala melakukan Bimtek dan sosialisasi mengenai SAP berbasis akrual dalam pelaporan asset, persediaan, piutang, dll yang sering menjadi obyek pemeriksaan BPK

\section{Daftar Referensi}

Badan Pemeriksa Keuangan Republik Indonesia. 2012. Buletin Teknis 01 tentang Pelaporan Hasil Pemeriksaan atas Laporan Keuangan Pemerintah. Jakarta: BPK-RI.

Badan Pemeriksa Keuangan Republik Indonesia.2015. Ikhtisar Hasil Pemeriksaan Semester I Tahun 2015. Jakarta: BPK-RI.

Badan Pemeriksa Keuangan Republik Indonesia.2015. Ikhtisar Hasil Pemeriksaan Semester II Tahun 2015. Jakarta: BPK-RI. 
Bungin, Burhan. 2014. Penelitian Kualitatif. Cetakan ke-7. Jakarta : Prenada Media Group.

Mahmudi. 2011. Manajemen Kinerja Sektor Publik (edisi 2). Yogyakarta : Unit Penerbit dan Percetakan Sekolah tinggi IImu Manajemen YKPN.

Moleong, Lexy J. 2006. Metodologi Penelitian Kualitatif. Bandung : Rosda.

Peraturan Pemerintah No.71 tahun 2010 tentang Standar Akuntansi Pemerintah. Jakarta

Peraturan Menteri Dalam Negeri No.64 tahun 2013 tentang Penerapan Standar Akuntansi Pemerintah berbasis akrual pada Pemda. Jakarta

Rangkuti, Freddy. 2008. Analisis SWOT Teknik Membedah Kasus Bisnis, Jakarta : PT Gramedia Pustaka Utama.

Surepno. 2015. Kunci Sukses dan Peran Strategis Implementasi Akuntansi Berbasis Akrual. Jurnal Dinamika Akuntansi. Vol 7 Nomor 2.

Tresnawati, F dan Apandi, RNN. 2016. Pengaruh Tindak Lanjut Hasil Pemeriksaan Terhadap Kualitas laporan Keuangan dengan Tingkat Pengungkapan Laporan Keuangan sebagai Variabel Moderating (Studi Empiris pada Kementerian/ Lembaga Republik Indonesia). Jurnal Akuntansi Riset. Vol 5 Nomor 2.

Undang-Undang No.17 tahun 2003 tentang Keuangan Negara. Jakarta

Undang-Undang No.1 tahun 2004 tentang Perbendaharaan Negara. Lembaran Negara Republik Indonesia Tahun 2004 Nomor 5. Jakarta. 